\title{
A NEW SPECIES OF PLEUROTHALLIDINAE (ORCHIDACEAE) FROM THE SOUTH-EAST OF ECUADOR
}

\author{
Luis E. Baquero ${ }^{1,3}$, Alison Fierro Minda $^{2} \&{\text { Justin } \text { Yeager }^{1}}^{1}$ \\ ${ }^{1}$ Grupo de Investigación en Medio Ambiente y Salud BIOMAS, \\ Carrera de Ingeniería Agroindustrial y Alimentos, Facultad de Ingeniería y Ciencias Agropecuarias, \\ Universidad de Las Américas, Calle José Queri, Quito 170137, Pichincha, Ecuador \\ ${ }^{2}$ Jardín Botánico de Quito, Pasaje \#34, Rumipampa E6-264 y Av Shyris, Interior Parque La Carolina, \\ Quito, 170135, Pichincha, Ecuador \\ ${ }^{3}$ Corresponding author: lbaquero@hotmail.com
}

\begin{abstract}
Porroglossum marcojimeneziorum, a new species of subtribe Pleurothallidinae, was discovered in Zamora Chinchipe province (south-east Ecuador) and is described here, including information about its phenology and ecology. Porroglossum marcojimeneziorum is compared with its most similar species, $P$. hirtzii, from which it differs by producing smaller flowers; the shortly-pubescent, triangular-ovate, obtuse lateral sepals and the blade of the lip obovate transversely expanded.

Resumen. Porroglosum marcojimeneziorum, una nueva especie de la subtribu Pleurothallidinae, fue descubierta en la provincia de Zamora Chinchipe (sur-este de Ecuador) y se describe aquí incluyendo información sobre la fenología y ecología de la especie. Porroglossum marcojimeneziorum es comparada con la especie $P$. hirtzii, de la que se diferencia por la flor más pequeña con sépalos laterales de pubescencia corta, de forma ovadatriangular y ápice obtuso, ampliamente abiertos y la lámina transversalmente obovada del labelo.
\end{abstract}

Key Words / Palabras clave: Porroglossum hirtzii, Porroglossum marcojimeneziorum, Zamora Chinchipe

Introduction. The genus Porroglossum Schlr. was created in 1920 by Rudolf Schlechter, who designated two species to the genus, $P$. mordax (Rchb.f.) H.R.Sweet (type) and P. muscosum (Rchb. f.) Schltr, both previously assigned to Masdevallia Ruiz \& Pav., however, Kraenzlin held the position that those species should stay in Masdevallia (Luer 1987). Nevertheless, Carlyle Luer not only recognized the genus described by Schlechter, but he additionally published a monograph of the genus in 1987, describing a total of 25 species of Porroglossum (Luer 1987).

The flowers of this genus are easily recognized for the apical anther and the mobile labellum that snaps shut when stimulated; combination of characteristics not found in any other Pleurothallidinae. A mobile lip can be found in Stelis rodrigoi (Luer) Pridgeon \& M.W.Chase and some species of the Specklinia subgen. Acostaea (Schltr.) Karremans. Plants of Porroglossum commonly have coriaceous leaves slightly to densely warty at the adaxial surface. The petals are projected forward, parallel to the column, with the upper and lower margins frequently expanded into acute teeth-like lobes. The number (absent, at one or both margins of the petals) and position (basal third, mid third or apical third) of these lobes are diagnostic for the species in the genus. A typical feature of the genus is that the lip is attached to the back side of the column foot. The blade of the mobile lip can be rhombic, terete, ovate, obovate, elliptic or rounded and always with a sulcus at the apex. The callus at the base of the blade can be longitudinal, transversal, simple or double (Luer 1987).

The 54 described Porroglossum species are distributed throughout the Andes of Venezuela, Colombia, Ecuador, Peru, with a single species in Bolivia, with a peak of diversity in Ecuador with (40 spp., 74\% of the genus) (Luer 1987, 1988, 1989, 1991, 1994, 1995, 1998, 2006, 2010, 2011, Luer \& Thoerle 2012, 2013, Kolanowska \& Szlachetko 2013, Merino et al. 2010, McDaniel et al. 2015, Baquero \& Iturralde 2017). Species of Porroglossum are found epiphytic in cloud-forests, from moderate to high elevation (between 1000 and $3200 \mathrm{~m}$ a.s.1.). In Ecuador, many species come from the Andean South-East slopes, and the Cutucú and Condor mountain ranges in Zamora Chinchipe and Morona Santiago provinces. Here, we describe and illustrate a recently discovered species, also from southeast Ecuador, which is compared with $P$. hirtzii Luer, likely the most closely related species. 


\section{TAXONOMIC TREATMENT}

Porroglossum marcojimeneziorum Baquero \& A.Fierro-Minda, sp. nov. (Fig. 1, 2, 3A, 3C, 4, 5A).

TYPE: Ecuador. Zamora Chinchipe: Palanda, Cerca de Palanda 4³8'58' S, 7908'46”'W, 1470 m, 24 Jan 2017, M. Jimenez 323 (holotype, QCNE) (Fig. 1-5).

Diagnosis: Porroglossum marcojimeneziorum is similar to $P$. hirtzii from which it differs by possessing smaller flowers (16-18 $\mathrm{mm} \mathrm{vs.} 20 \mathrm{~mm}$ of the corolla), with widely opened lateral sepals ( $v s$. a larger flower with the lateral sepals inflexed forward), triangular ovate, obtuse, and white with cream colored nerves in the adaxial side (vs. triangular ovate, subacute, and white suffused with pale rose in the adaxial side), the callus of the lip transversely triangular and longitudinally notched in the middle ( $v s$. the low, erect, transverse, entire callus), the blade of the lip transversely obovate stained with purple ( $v s$. rhomboid and white) (Fig. 1-5).

Epiphytic caespitose herb, up $65 \mathrm{~mm}$ tall. Roots slender, ca. $1.5 \mathrm{~mm}$ in diameter. Ramicauls nigrescent, erect, slender, $c a .10 .0-30.0 \times 1.8 \mathrm{~mm}$, enclosed by 2-3 tubular sheaths. Leaf erect-arcuate, coriaceous, 4-7 cm long including the petiole, the blade narrowly obovate, $3.0-4.5 \times 0.7-1.0 \mathrm{~cm}$, acute, the base attenuate. Inflorescence a congested, successively single-flowered raceme, emerging from low on the ramicaul, the flowers resupinate, peduncle glabrous, erect to sub-erect, $7.5-8.5 \mathrm{~cm}$ long, with 2 tubular distant bracts; floral bracts tubular, imbricating, 4-7 $\mathrm{mm}$ long, pedicel 7-10 mm long. Ovary curved, rugose, $3.2 \mathrm{~mm}$. Dorsal sepal narrowly ovate, acute, three-veined, convex at the apical third, concave below and long pubescent towards the apical third, 8.0-9.0 $\times$ $3.2-3.5 \mathrm{~mm}, 3$-veined, connate at the base $(1.4 \mathrm{~mm})$ to the lateral sepals, shortly-pubescent at the margins below the apical third; white, with yellowish green in both surfaces, adaxial and abaxial side suffused with rose and veins elevated at the abaxial side. Lateral sepals ovate, obtuse to subacute apex, snow-white, slightly translucent, slightly pubescent (including margins) toward the apex, 8.0-9.0 $\times 4.5-4.8 \mathrm{~mm}$, connate to each other $(1 \mathrm{~mm})$ at the base; with three cream veins, yellowish green in the basal half and elevated abaxially. Petals cream, translucent, with a yellowish green mid vein, waxy, oblong, curved, 3.0 $\times 0.8 \mathrm{~mm}$, narrowed in the middle third, the apex thickened, slightly dilated, rounded, the lower margin with an obtusely angled lobe in the lower third. Lip white, suffused with purple towards the apex; the blade shortly pubescent, obovate, the lateral angles rounded, the apex obtuse to sub-truncate, sulcate medially, 4.2 $\times 4.4 \mathrm{~mm}$; the base with a low, transversely triangular callus longitudinally notched in the middle, deflexed below into a strap-like claw bent with tension around the free apex of the column-foot, hinged to the back surface of the column-foot. Column stout, semiterete, $2.5 \mathrm{~mm}$ long, swollen ventrally with a $0.8 \mathrm{~m}$ in diameter and round stigma. Pollinia two, yellow, $1 \mathrm{~mm}$ long. Fruit a dehiscent capsule, $18 \mathrm{~mm} \times 9 \mathrm{~mm}$.

Paratype: Ecuador. Zamora Chinchipe: Palanda, Cerca de Palanda 4³9' 1" S, 798'39" W, 1405 m, 3 May 2017, LB 3133 (paratype, QCNE) (Fig. 2A-B).

Eponymy: Named after Marco M. Jimenez (father) and Marco M. Jimenez (son) from Zamora, Ecuador; both passionate orchid lovers. Marco M. Jimenez V., the father, has made notable discoveries along the past 40 years and his son represents a member of the new generation orchid researchers from Ecuador. Both of them initially observed the first plants of the new species presented here.

Habitat and ecology: Porroglossum marcojimeneziorum has been found growing epiphytic in low elevation cloud forest of the south of Ecuador. Two populations of this species have been found growing nearby at a similar elevation (between 1400-1500 $\mathrm{m}$ in elevation), where, around 15 plants have been witnessed growing between the two sites.

Phenology: Plants of Porroglossum marcojimeneziorum grown in Zamora were recoded flowering from July through November. A plant cultivated at Quito Botanical Gardens has not flowered in the past two years, but undeveloped inflorescences. This is perhaps attributable to the colder weather in Quito. However, plants in situ have been observed flowering during the same time periods across the past two years.

Of all the species of Porroglossum within the 


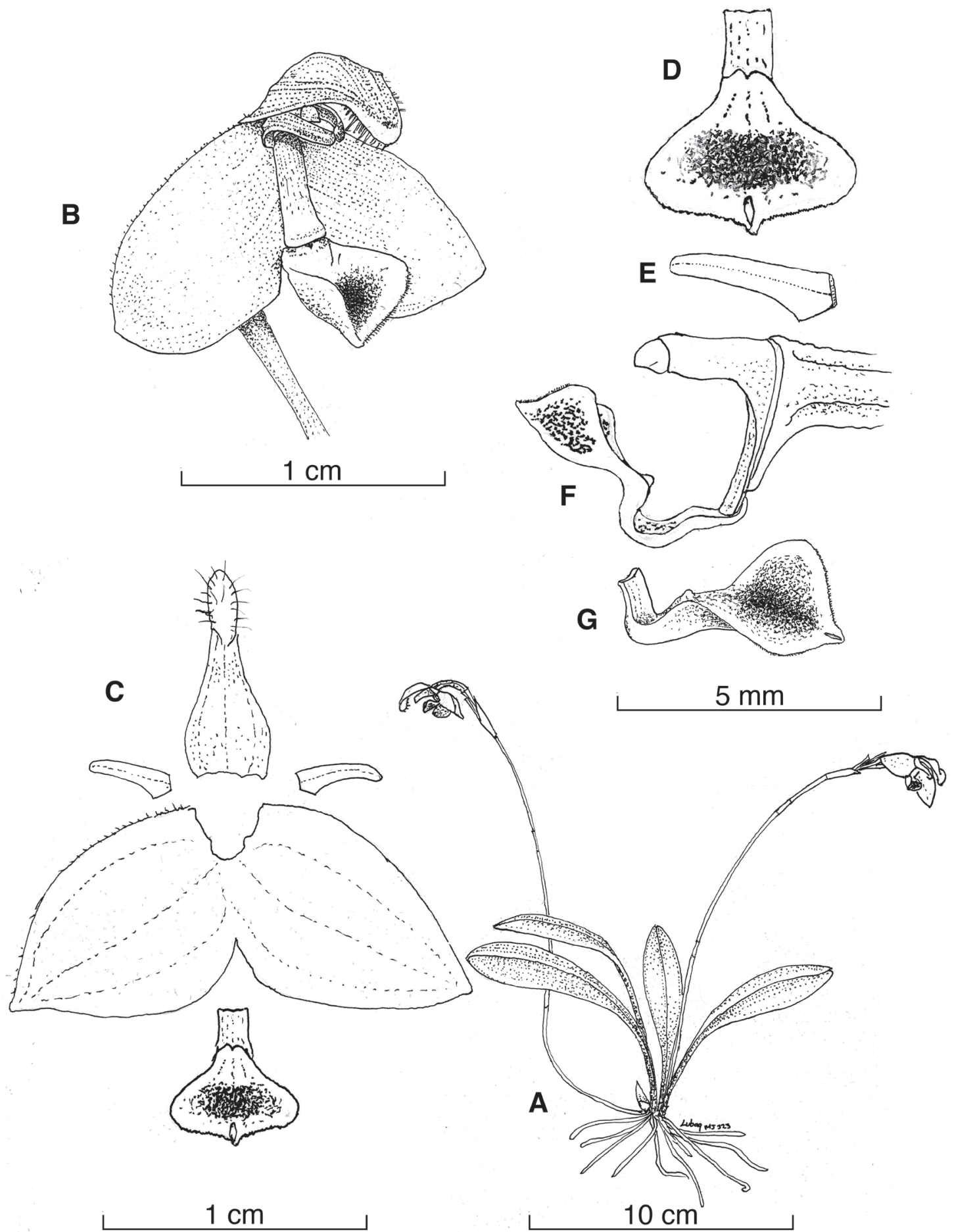

FiguRe 1. Porroglossum marcojimeneziorum Baquero \& A.Fierro-Minda. A. Habit. B. Flower, 3/4 view. C. Dissected perianth. D. Adaxial view of the lip and callus. E. Petal. F. Lateral view of the column and lip. G. Lateral view of the lip. Illustration by L. E. Baquero, based on the holotype, Marco Jimenez 322 (QCNE). 

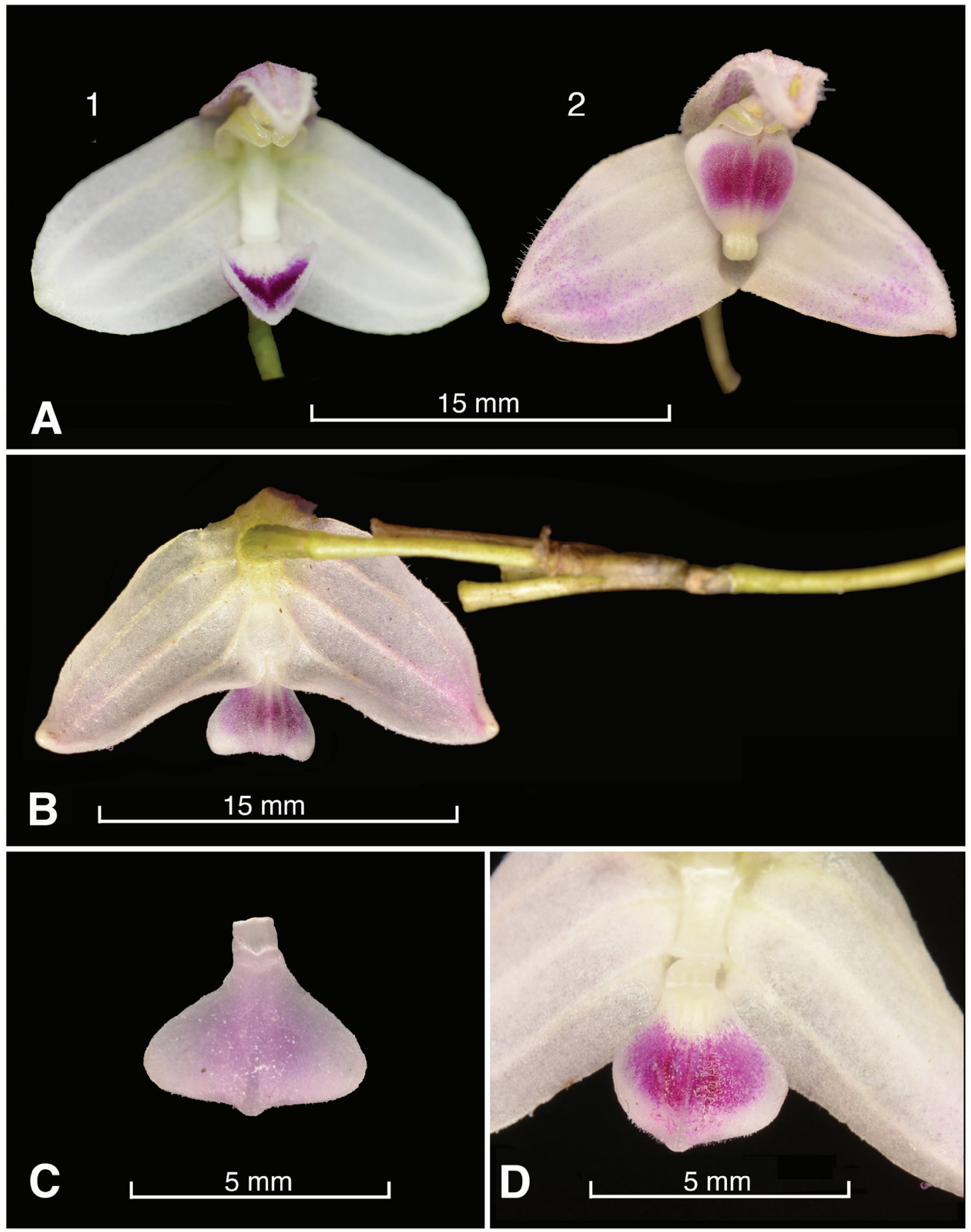

Figure 2. Porroglossum marcojimeneziorum Baquero \& A.Fierro-Minda. A1. Flower with the lip opened (based on MJ 332, holotype, QCNE). A2. Flower with the lip closed (based on $L B$ 3133, paratype, QCNE). B. View from behind with lip opened and peduncles. C. Lip in expanded position from a preserved flower in alcohol. D. Lip in opened position. Photos by L. E. Baquero (A1-D, except B) and M. M. Jimenez L. (B), based on MJ 332 (A1) and on LB 3133 (A2-D). 

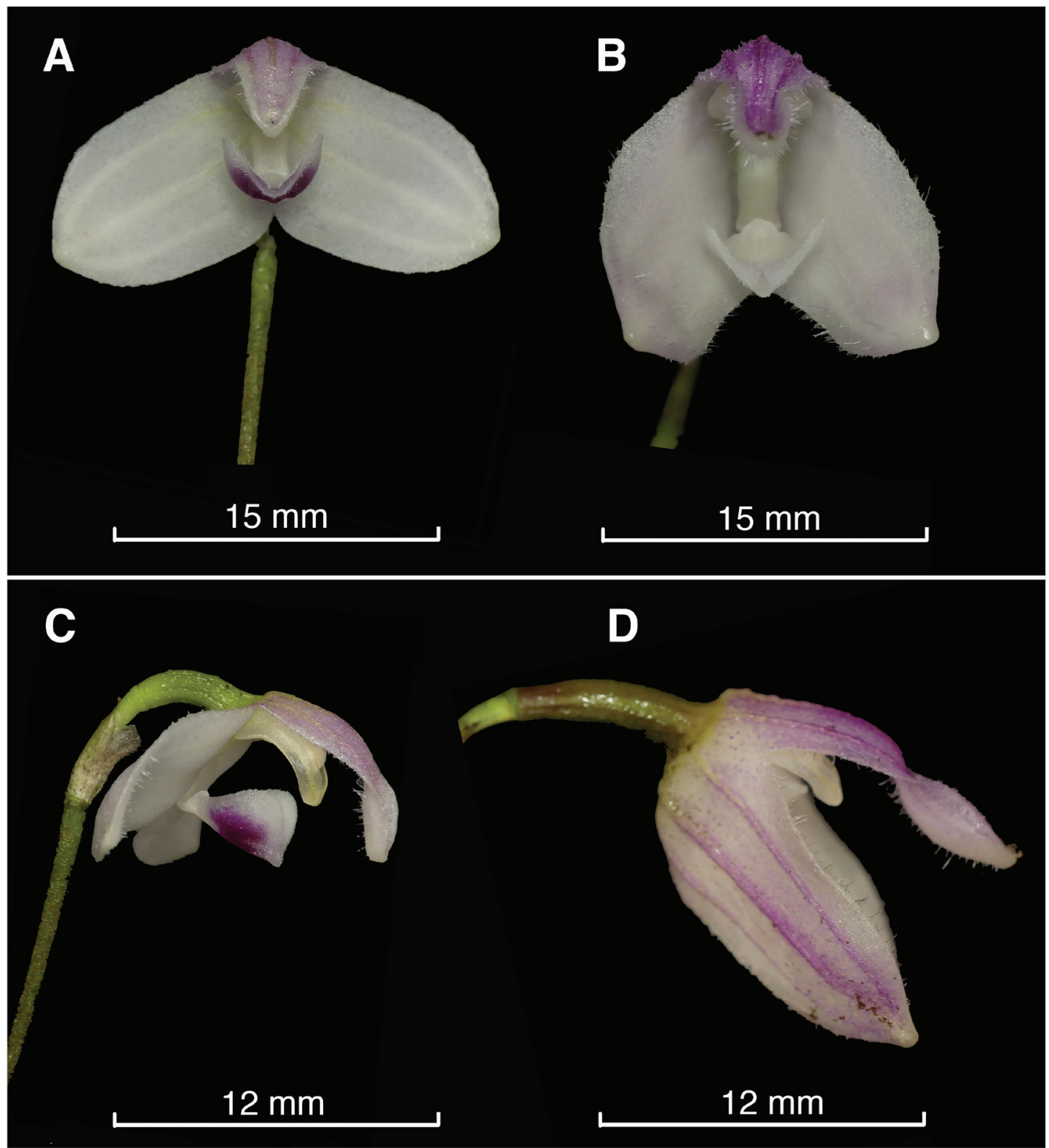

Figure 3. Comparison of Porroglossum marcojimeneziorum Baquero \& A.Fierro-Minda and P. hirtzii Luer. A. Frontal view of $P$. marcojimeneziorum. B. Frontal view of $P$. hirtzii. C. Lateral view of $P$. marcojimeneziorum. D. Lateral view of $P$. hirtzii. Photos by M. M. Jimenez L. (A-B) and L. E. Baquero (C-D).

subgenus Porroglossum, P. hirtzii was the only known species with tail-less sepals. Also, the white, pubescent flowers immediately help to distinguish $P$. hirtzii from the other species in the genus. Nevertheless, $P$. marcojimeneziorum is the second known species in the genus which shares this feature (Fig. 3, 5). Although, both species are similar and both come from the eastern slopes of the Ecuadorian Andes, P. marcojimeneziorum was discovered further south, and all known individuals from natural populations share unique morphological characteristics which separate them from P. hirtzii. The inflorescences of $P$. marcojimeneziorum are erect 

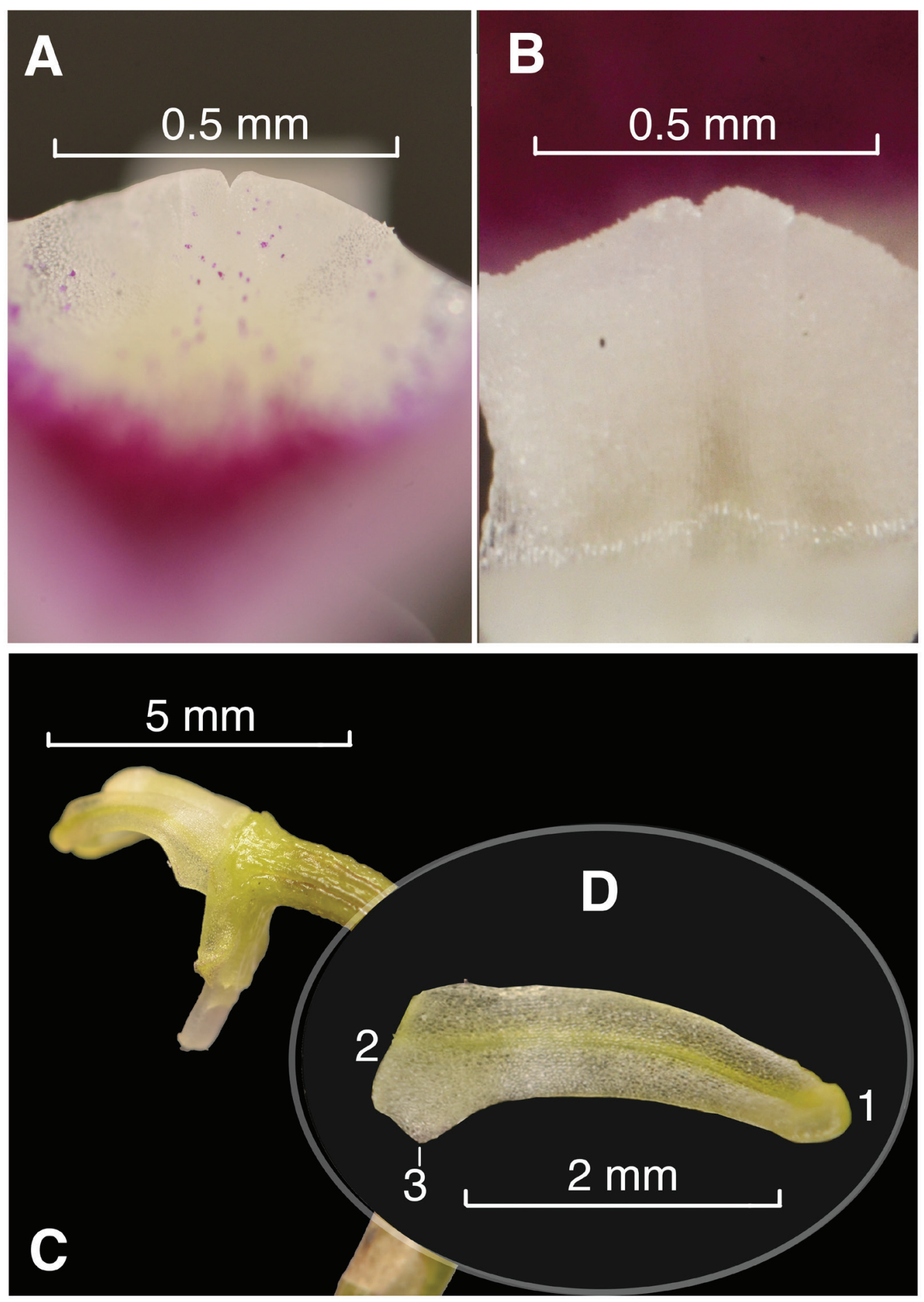

Figure 4. Porroglossum marcojimeneziorum Baquero \& A.Fierro-Minda A. Frontal view of the lip callus. B. Back view of the lip callus. C. Lateral view of the petal and column. D. Close-up of the petal. D1. Apex. D2. Base. D3. Wing-like lobe of the base of the petal. Photos by L. E. Baquero. 

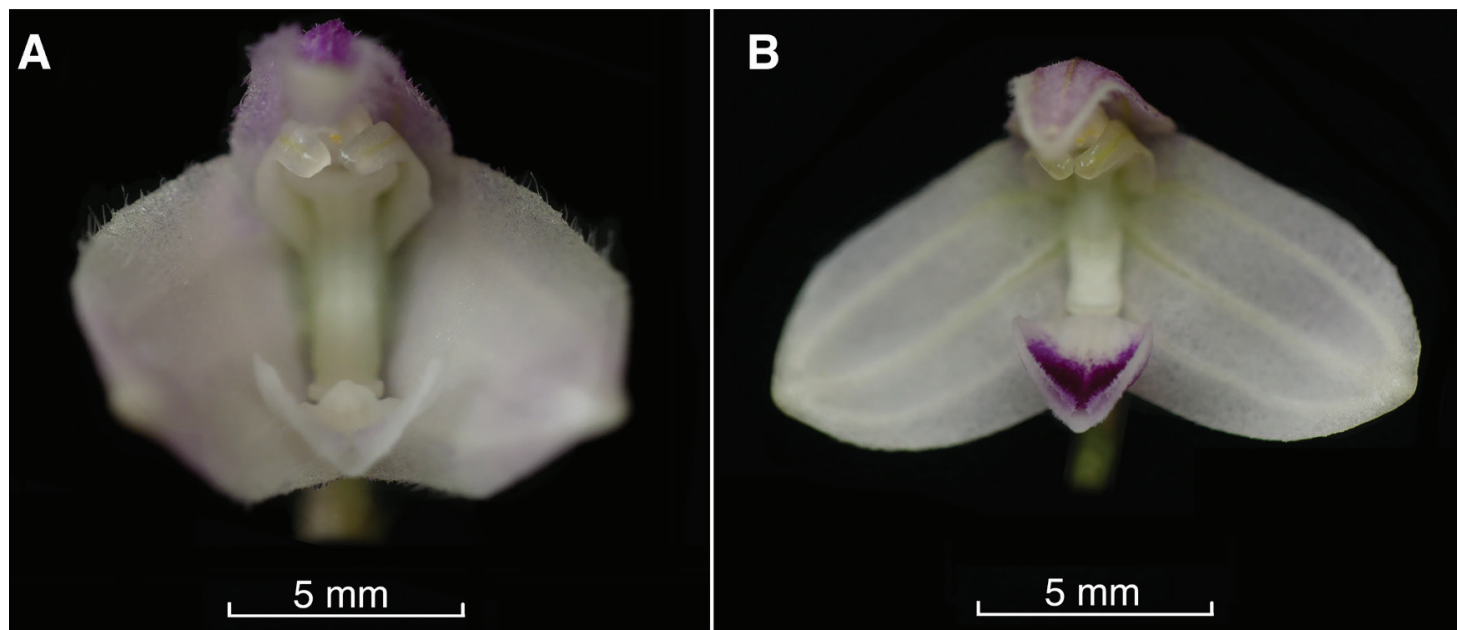

Figure 5. Flowers of Porroglossum hirtzii Luer (A) and Porroglossum marcojimeneziorum Baquero \& A.Fierro-Minda (B). Photos by M. M. Jimenez L.

or sub-erect and bare smaller flowers (from $16 \mathrm{~mm}$ long) compared to the bigger flowers in $P$. hirtzii (from $20 \mathrm{~mm}$ long) which has horizontal or even descending inflorescences. The flowers of $P$. hirtzii never open widely, and the sepals project more or less to forward, whereas the flowers of $P$. marcojimeneziorum have widely opened lateral sepals, even a little reflexed in some plants. The lips of both species are also different in shape and pigmentation; the consistently white rhomboid blade of the lip in P. hitzii is different from the widely obovate and stained with purple blade of the lip in P. marcojimeneziorum (Fig. 1-5).

Conservation Status: At the moment, the plants known of this new species grow in an unprotected area where mining activity is abundant. Although the species seems to have healthy populations, in the event forest cutting or invasive mining activities take place and destroy habitats, the species might be placed at risk. As we have previously suggested, more research is needed to get a better understanding of populations of $P$. marcojimeneziorum. Being such an attractive species of a commonly cultivated genus, illegal collecting and exporting are additional threats for the species.

ACKNOWLEDGEMENTS. We acknowledge Universidad de Las Américas (UDLA) for funding research on orchids in Ecuador. The Ministerio del Ambiente del Ecuador is acknowledged for issuing the Environmental Research Permit No. 008-2016-IC-FLO-DNB/MA. We acknowledge the Jimenez family for the access to their orchid collections and the help with information and specimens needed for this study. Finally, we are grateful to the Editor and the anonymous reviewers for suggestions on the manuscript.

\section{LITERATURE CITED}

Baquero, L. \& Iturralde, G. (2017). Porroglossum raoi, a new species of Pleurothallidinae (Orchidaceae) from Ecuador. Lankesteriana, 17(1), 49-53.

Luer, C. A. (1987). Icones Pleurothallidinarum IV. Systematics of the genus Porroglossum. Monographs in Systematic Botany from the Missouri Botanical Garden, 24, 25-90.

Luer, C. A. (1988). Icones Pleurothallidinarum V. Systematics of Dresslerella and Scaphosepalum. Addenda to Porroglossum. Monographs in Systematic Botany from the Missouri Botanical Garden, 26, 108-109.

Luer, C. A. (1989). Icones Pleurothallidinarum VI. Systematics of Pleurothallis subgenus Ancipitia, subgenus Scopula and Trisetella. Addendum to Porroglossum. Monographs in Systematic Botany from the Missouri Botanical Garden, 31, 124-125.

Luer, C. A. (1991). Icones Pleurothallidinarum VIII. Systematics of Lepanthopsis, Octomeria subgenus Pleurothallopsis, Restrepiella, Restrepiopsis, Salpistele, and Teagueia: addenda to Platystele, Porroglossum and Scaphosepalum (Orchidaceae). Monographs in Systematic Botany from the Missouri Botanical Garden, 39, 152-156. 
Luer, C. A. (1994). Icones Pleurothallidinarum XII. Systematics of the genus Lepanthes subgenus Brachycladium and Pleurothallis subgenus Aenigma subgenus Elongatia subgenus Kraenzlinella. Addenda to Dracula, Lepanthopsis, Myoxanthus, Platystele, Porroglossum and Trisetella. Monographs in Systematic Botany from the Missouri Botanical Garden, 52, 134.

Luer, C. A. (1995). Icones Pleurothallidinarum XII. Systematics of the genus Brachionidium. Addenda to Dresslerella, Platystele and Porroglossum. Monographs in Systematic Botany from the Missouri Botanical Garden, 24, 144-145.

Luer, C. A. (1998). Icones Pleurothallidinarum XVII. Pleurothallis Subgenus Pleurothallis Sections Pleurothallis and Acroniae, Pleurothallis Subgenera. Addenda to Dracula, Lepanthes, Masdevallia, Porroglossum and Scaphosepalum. Monographs in Systematic Botany from the Missouri Botanical Garden, 72, 114-115.

Luer, C. A. (2006). Icones Pleurothallidinarum XXVIII. A reconsideration of Masdevallia, and the systematics of Specklinia and Vegetatively similar taxa (Orchidaceae). Addendum to Porroglossum. Monographs in Systematic Botany from the Missouri Botanical Garden, 105, 253-254.

Luer, C. A. (2010). Icones Pleurothallidinarum XXXI. Lepanthes of Bolivia. Systematics of Octomeria species north and west of Brazil. Monographs in Systematic Botany from the Missouri Botanical Garden, 120, 147-153.

Luer, C. A. (2011). Miscellaneous New Species in the Pleurothallidinae (Orchidaceae) Excluding Species from Brazil. Harvard Papers in Botany, 16(2), 341-345.

Luer, C. A. \& Thoerle, L. (2012). Miscellaneous New Species in the Pleurothallidinae (Orchidaceae). Harvard Papers in Botany, 17(2), 333-368.

Luer, C. A. \& Thoerle, L. (2013). Miscellaneous New Species in the Pleurothallidinae (Orchidaceae). Harvard Papers in Botany, 18(2), 183-185.

Kolanowska, M. \& Szlachetko, D. (2013). A new species of Porroglossum (Orchidaceae, Pleurothallidinae) from Colombia. Polish Botanical Journal, 58(2), 629-632.

McDaniel, J., Portilla, J. \& Merino, G. (2015). A new Porroglossum. Orchids, 84(8), 503.

Merino, G., Doucette, A. \& Pupulin, F. (2010). New species of Porroglossum (Orchidaceae: Pleurothallidinae) from Ecuador. Lankesteriana, 9(3), 459-466. 